\title{
Dehydrogenative Sn-E (E = S, Se) bond formation catalyzed by an iron complex
}

\section{Masumi Itazaki, Yudai Ogawa, Wataru Nakamura, Hiroshi Nakazawa}

\begin{tabular}{|c|c|}
\hline Citation & Heteroatom Chemistry, 29(5-6); e21461 \\
\hline Issue Date & $2018-12-04$ \\
\hline Type & Journal Article \\
\hline Textversion & Author \\
\hline Rights & $\begin{array}{l}\text { This is the peer reviewed version of the following article: Heteroatom Chemistry, Vol.29, } \\
\text { Issu.5-6, e21461., which has been published in final form at } \\
\text { https://doi.org/10.1002/hc. } 21461 \text {. This article may be used for non-commercial purposes } \\
\text { in accordance with Wiley Terms and Conditions for Self-Archiving. }\end{array}$ \\
\hline DOI & 10.1002/hc.21461 \\
\hline
\end{tabular}

Self-Archiving by Author(s)

Placed on: Osaka City University

ITAZAKI, M., OGAWA, Y., NAKAMURA, W., \& NAKAZAWA, H. (2018). Dehydrogenative Sn-E (E = $\mathrm{S}$, Se) bond formation catalyzed by an iron complex. Heteroatom Chemistry. 29, e21461. Doi: 10.1002/hc. 21461 


\title{
Dehydrogenative Sn-E (E = S, Se) Bond Formation Catalyzed by an Iron Complex
}

\author{
Masumi Itazaki* \\ Yudai Ogawa \\ Wataru Nakamura \\ Hiroshi Nakazawa* \\ Department of Chemistry, Graduate School of Science, Osaka City University, \\ Sugimoto 3-3-138, Sumiyoshi-ku, Osaka 558-8585, Japan.
}

\begin{abstract}
Iron complex-catalyzed dehydrogenative $\mathrm{Sn}-\mathrm{E}(\mathrm{E}=\mathrm{S}, \mathrm{Se})$ bond formation of hydrostannane with thiol and selenol was achieved. All new compounds were fully characterized using ${ }^{1} \mathrm{H},{ }^{13} \mathrm{C}\left\{{ }^{1} \mathrm{H}\right\},{ }^{77} \mathrm{Se}\left\{{ }^{1} \mathrm{H}\right\}$, and ${ }^{119} \mathrm{Sn}\left\{{ }^{1} \mathrm{H}\right\}$ NMR measurements and elemental analyses. The structure of 1,1'-(1,3-dithia-2,2-dibutylstanyl)-[3]ferrocenophane was confirmed by single crystal X-ray diffraction.
\end{abstract}

Keywords Iron; Thiol; Selenol; Hydrostannane; Dehydrogenative Coupling

Received September@, 2018.

Address correspondence to M. Itazaki and H. Nakazawa, Department of Chemistry, Graduate School of Science, Osaka City University, 3-3-138 Sugimoto, Sumiyoshi-ku, Osaka 558-8585, Japan.

E-mail:mitazaki@sci.osaka-cu.ac.jp,nakazawa@sci.osaka-cu.ac.jp 


\section{INTRODUCTION}

Compounds having an $\mathrm{Sn}-\mathrm{E}(\mathrm{E}=\mathrm{S}, \mathrm{Se})$ bond have attracted considerable attention because these compounds act as convenient reagents for the preparation of thiol esters from acid chloride[1] and for regioselective ring opening reaction of epoxides.[2] Dehydrogenative coupling of hydrostannane with thiol and selenol catalyzed by a transition metal complex is one of effective methods for $\mathrm{Sn}-\mathrm{E}(\mathrm{E}=\mathrm{S}, \mathrm{Se})$ bond formation because it does not involve any byproducts (except easily removable $\mathrm{H}_{2}$ ) such as unnecessary inorganic salts. However, organic sulfides are generally known to serve as a catalyst poison. Actually, only one example of catalytic dehydrogenative Sn-S coupling reaction has been reported by Talley and Colley in 1981 (Scheme 1) in which a Rh complex catalyst was used.[3]

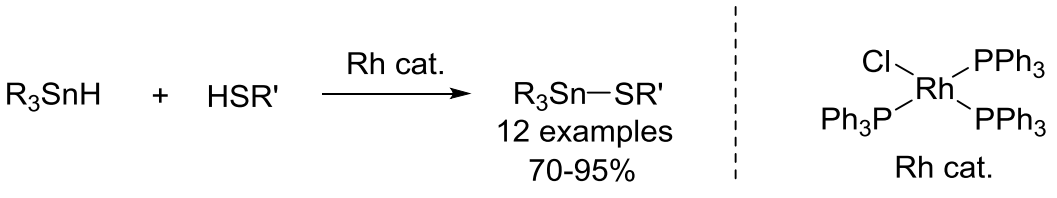

\section{SCHEME 1}

Previously, we reported dehydrogenative coupling of thiol with hydrosilane catalyzed by an iron complex (Scheme 2),[4] in which the corresponding $\mathrm{Si}-\mathrm{S}$ coupling products were obtained in low to excellent yields.

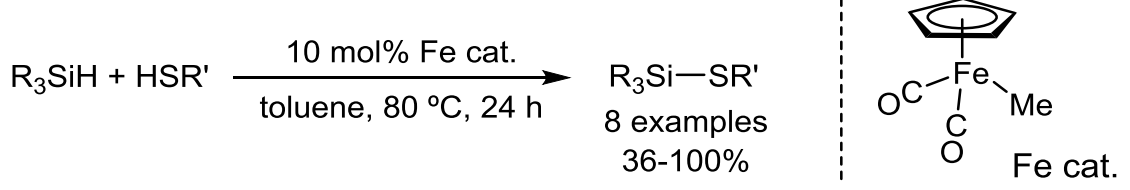

\section{SCHEME 2}

This $\mathrm{Si}-\mathrm{S}$ bond formation promoted by an iron complex stimulated us to challenge dehydrogenative $\mathrm{Sn}-\mathrm{S}$ coupling catalyzed by a transition metal complex. Herein, we report the first example of dehydrogenative $\mathrm{Sn}-\mathrm{E}(\mathrm{E}=\mathrm{S}, \mathrm{Se})$ bond formation catalyzed by a very simple, piano-stool type iron complex $\left[\mathrm{CpFe}(\mathrm{CO})_{2}(\mathrm{Me})\right]\left(\mathrm{Cp}\right.$ stands for $\left.\eta^{5}-\mathrm{C}_{5} \mathrm{H}_{5}\right)($ Scheme 3$)$.
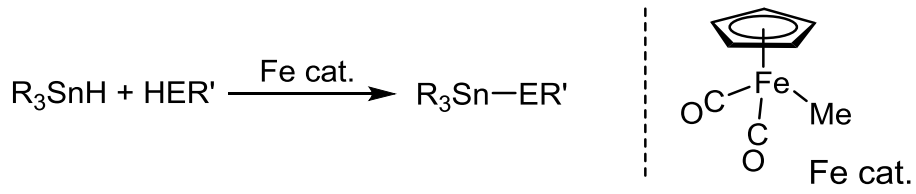


\section{SCHEME 3}

\section{RESULTS AND DISCUSSION}

A toluene- $d_{8}$ solution containing ${ }^{n} \mathrm{Bu}_{2} \mathrm{SnH}_{2}, 2$ equiv. of $\mathrm{HSPh}$, and $10 \mathrm{~mol} \%$ (vs $\left.{ }^{n} \mathrm{Bu}_{2} \mathrm{SnH}_{2}\right)$ of $\left[\mathrm{CpFe}(\mathrm{CO})_{2}(\mathrm{Me})\right]$ was heated at $50{ }^{\circ} \mathrm{C}$ for $5 \mathrm{~h}$. After the reaction, the toluene- $d_{8}$ solution was subjected to the ${ }^{1} \mathrm{H}$ NMR measurement, revealing the formation of the corresponding Sn-S coupling product ${ }^{n} \mathrm{Bu}_{2} \mathrm{Sn}(\mathrm{SPh})_{2}$ (1), in 93\% yield (Scheme 4). When $\mathrm{HS}{ }^{t} \mathrm{Bu}$ was used, a higher reaction temperature $\left(80^{\circ} \mathrm{C}\right)$ and a longer reaction time $(14 \mathrm{~h})$ were required, but the corresponding ${ }^{n} \mathrm{Bu}_{2} \mathrm{Sn}\left(\mathrm{S}^{t} \mathrm{Bu}\right)_{2}$ was formed in $93 \%$ yield.

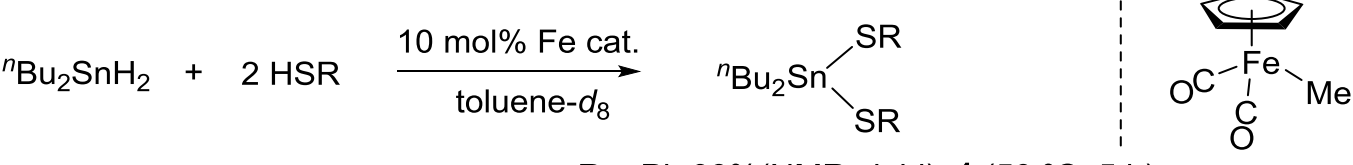

$$
\begin{aligned}
& \mathrm{R}=\mathrm{Ph} 93 \%\left(\mathrm{NMR} \text { yield): } \mathbf{1}\left(50^{\circ} \mathrm{C}, 5 \mathrm{~h}\right) \quad\right. \text { Fe cat }
\end{aligned}
$$

\section{SCHEME 4}

Next, we examined the reaction of 1,1'-ferrocenedithiol with secondary hydrostannane in our catalytic system with the hope of selective formation of an ansa-type compound such as a [3]ferrocenophane. 1,1'-Ferrocenedithiol [(HSCp $)_{2} \mathrm{Fe}$ ] reacted with ${ }^{n} \mathrm{Bu}_{2} \mathrm{SnH}_{2}$ in a 1:1 molar ratio at $80{ }^{\circ} \mathrm{C}$ for $1 \mathrm{~h}$ in the presence of $\left[\mathrm{CpFe}(\mathrm{CO})_{2}(\mathrm{Me})\right]$ to give the desired 1,1'-(1,3-dithia-2,2dibutylstanyl)-[3]ferrocenophane 3 in $88 \%$ yield (Scheme 5). Without the catalyst the reaction underwent very slowly. Therefore, it was thought that the iron complex acted as a catalyst. In addition, this reaction also took place under mild conditions $\left(50{ }^{\circ} \mathrm{C}, 4 \mathrm{~h}\right)$.

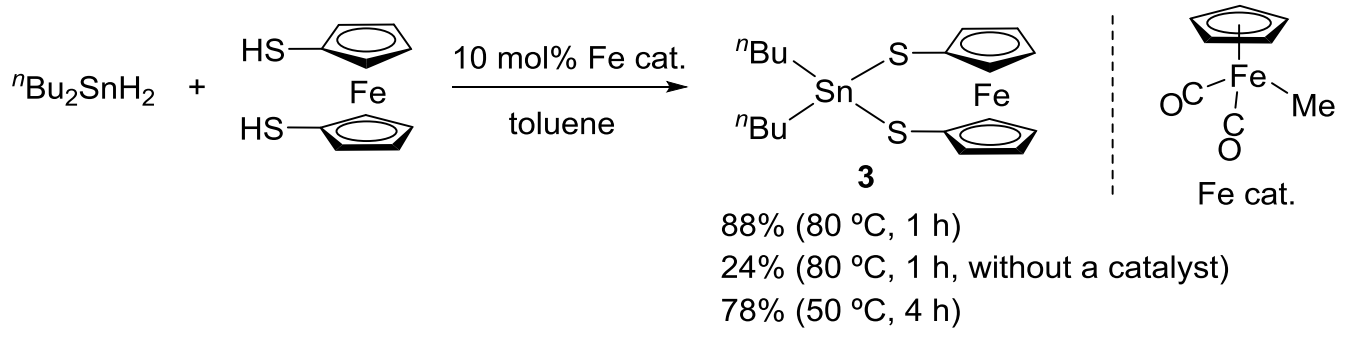

\section{SCHEME 5}


The molecular structure of $\mathbf{3}$ was determined using single crystal X-ray diffraction. Two independent molecules of $\mathbf{3}$ crystallized in the unit cell. As these are basically the same, the ORTEP drawing of $\mathbf{3}$ (Fe1 molecule) is shown in Fig. 1 and the crystal data are listed in Table 1. The Sn center adopts a typical tetrahedral geometry and has two ${ }^{n} \mathrm{Bu}$ substituents and a ferrocene1,1'-dithiolato ligand. The Sn-S bond distances (2.4297(13), 2.4364(13) A for Fe1 molecule, 2.4313(13), 2.4378(13) for $\mathrm{Fe} 2$ molecule) in $\mathbf{3}$ are longer than those of previously reported analogous bis(ferrocene-1,1'-dithiolato)stannane $(2.39,2.41 \AA$ ̊).[5]

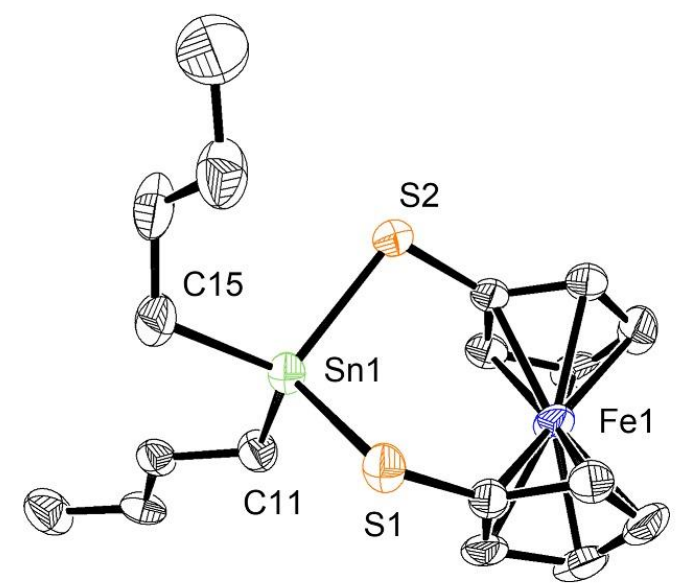

Fig. 1. ORTEP drawing of 3 (Fe1 molecule). Selected bond lengths $(\AA)$ and angles $\left({ }^{\circ}\right)$ : $\operatorname{Sn}(1)-\mathrm{S}(1) 2.4297(13)$, $\mathrm{Sn}(1)-\mathrm{S}(2)$ 2.4364(13), S(1)-Sn(1)-S(2) 100.52(5), C(11)-Sn(1)-C(15) 114.16(16) for Fe1 molecule, Sn(2)$\mathrm{S}(3)$ 2.4378(13), Sn(2)-S(4) 2.4313(13), S(3)-Sn(2)-S(4) 100.52(5), C(29)-Sn(2)-C(33) 116.53(16) for Fe2 molecule.

\begin{tabular}{ll|ll}
\hline \multicolumn{3}{l}{ Table 1. Crystal data of $\mathbf{3}$} & \\
\hline Empirical formula & $\mathrm{C}_{18} \mathrm{H}_{26} \mathrm{~S}_{2} \mathrm{SnFe}$ & Volume $\left(\AA^{3}\right)$ & $1910.6(12)$ \\
Formula weight & 481.05 & $Z$ & 4 \\
$T(\mathrm{~K})$ & $200(2)$ & $\rho_{\text {calcd }}\left(\mathrm{g} \mathrm{cm}^{-3}\right)$ & 1.672 \\
Crystal system & Triclinic & $F(000)$ & 968 \\
Space group & $P-1$ & Crystal size $\left(\mathrm{mm}^{3}\right)$ & $0.48 \times 0.020 \times 0.010$ \\
$a(\AA)$ & $10.622(4)$ & Reflections collected & 19827 \\
$b(\AA)$ & Independent reflections $(\mathrm{R}(\mathrm{int}))$ & $8594(0.0489)$ \\
$c(\AA)$ & Final $R_{1}(I>2 \sigma(I))$ & 0.0388 \\
$\alpha\left(^{\circ}\right)$ & $10.649(4)$ & Final $R_{1} / \mathrm{w} R_{2}($ all data $)$ & $0.0752 / 0.0729$ \\
$\beta\left({ }^{\circ}\right)$ & $18.020(7)$ & Goodness of fit & 1.011 \\
$\gamma\left({ }^{\circ}\right)$ & $89.309(11)$ & Volume $\left(\AA^{3}\right)$ & $1910.6(12)$ \\
\hline
\end{tabular}


The corresponding 1,1'-(1,3-diseleno-2,2-dibutylstanyl)-[3]ferrocenophane 4 was also obtained by the reaction of 1,1'-ferrocenediselenol instead of 1,1'-ferrocenedithiol with ${ }^{n} \mathrm{Bu}_{2} \mathrm{SnH}_{2}$ (Scheme 6).

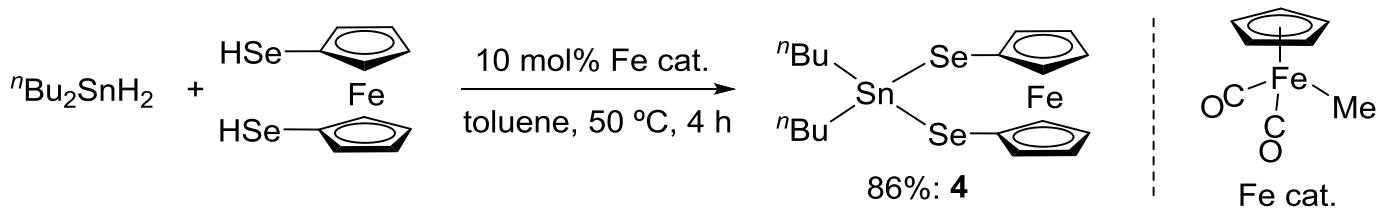

\section{SCHEME 6}

In the ${ }^{1} \mathrm{H}$ NMR spectrum of 4 , a signal attributable to $\mathrm{H}-\mathrm{Sn}$ was not observed. The ${ }^{77} \mathrm{Se}\left\{{ }^{1} \mathrm{H}\right\}$ NMR spectrum showed a signal at $\delta-210.10$ flanked by both ${ }^{117} \mathrm{Sn}$ and ${ }^{119} \mathrm{Sn}$ satellites $\left({ }^{1} J\left({ }^{117} \mathrm{Sn}-{ }^{77} \mathrm{Se}\right)=1270 \mathrm{~Hz},{ }^{1} J\left({ }^{119} \mathrm{Sn}-{ }^{77} \mathrm{Se}\right)=1331 \mathrm{~Hz}\right)($ Fig. 2$)$ and a singlet at $\delta 161.56\left({ }^{1} J\left({ }^{77} \mathrm{Se}-\right.\right.$ $\left.{ }^{119} \mathrm{Sn}\right)=1331 \mathrm{~Hz}$ ) was observed in ${ }^{119} \mathrm{Sn}\left\{{ }^{1} \mathrm{H}\right\}$ NMR spectrum. These results showed that two equivariant $\mathrm{Sn}-\mathrm{Se}$ bonds in 4 were formed by the dehydrogenative coupling reaction.

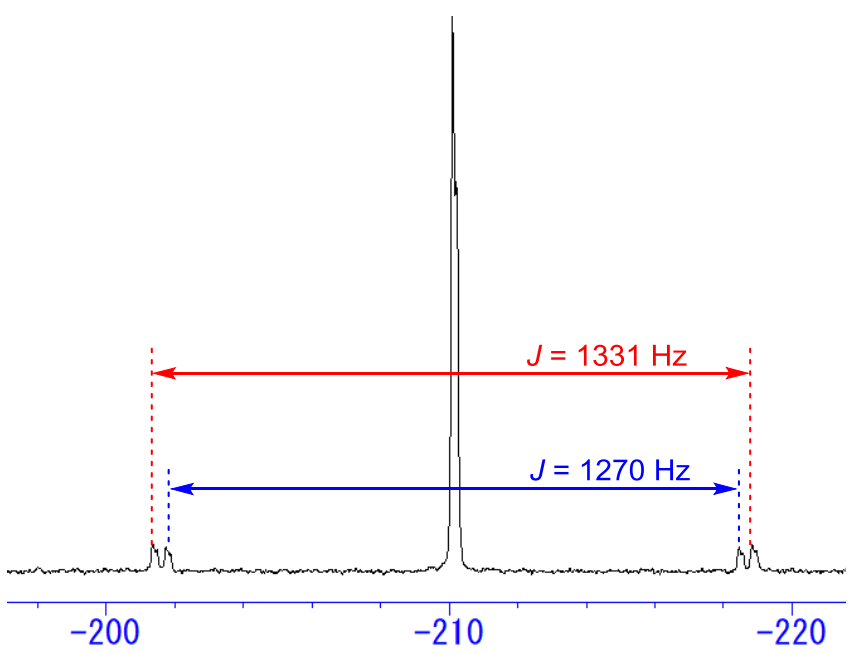

Fig. 2. ${ }^{77} \mathrm{Se}\left\{{ }^{1} \mathrm{H}\right\}$ NMR spectrum $\left(76 \mathrm{MHz}, \mathrm{C}_{6} \mathrm{D}_{6}\right.$, r.t.) of 4 .

We also checked the reaction of tertiary hydrostannane with selenol. In our system, the reaction of ${ }^{n} \mathrm{Bu}_{3} \mathrm{SnH}$ with 1,1'-ferrocenediselenol $\left[(\mathrm{HSeCp})_{2} \mathrm{Fe}\right]$ in a 2:1 molar ratio at $50{ }^{\circ} \mathrm{C}$ for 6 $\mathrm{h}$ in the presence of $\left[\mathrm{CpFe}(\mathrm{CO})_{2}(\mathrm{Me})\right]$ afforded the desired 1,1'-bis(tributylstanylseleno)ferrocene 
$\left[\left({ }^{n} \mathrm{Bu}_{3} \mathrm{SnSeCp}\right)_{2} \mathrm{Fe}\right]$ 5. Furthermore, the desired coupling products $\mathrm{R}_{3} \mathrm{Sn}-\mathrm{SePh}\left(\mathrm{R}={ }^{n} \mathrm{Bu}: \mathbf{6}, \mathrm{Ph}\right.$ :

7) were obtained by the reaction of tertiary hydrostannane $\mathrm{R}_{3} \mathrm{SnH}$ with benzeneselenol $\mathrm{HSePh}$ (Scheme 7). This paper shows the first example of catalytic $\mathrm{Sn}-\mathrm{Se}$ bond formation.

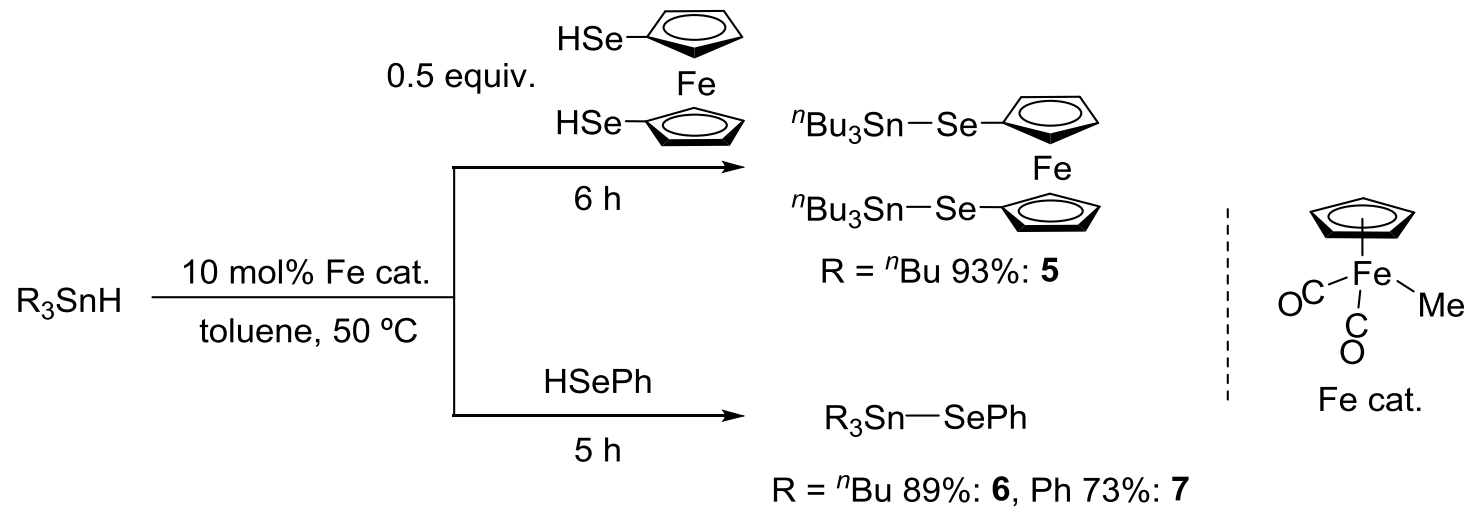

\section{SCHEME 7}

In order to obtain insight into the reaction pathway of dehydrogenative $\mathrm{Sn}-\mathrm{E}(\mathrm{E}=\mathrm{S}, \mathrm{Se})$ bond formation, the stoichiometric reaction of $\left[\mathrm{CpFe}(\mathrm{CO})_{2}(\mathrm{Me})\right]$ with $\mathrm{HSePh}$ was examined. The reaction afforded the Se-bridged iron dimer complex $[\mathrm{CpFe}(\mathrm{CO})(\mu-\mathrm{SePh})]_{2} \mathbf{8}(s y n:$ anti $=c a$. $4: 1$ ) in $22 \%$ yield (Scheme 8 ).

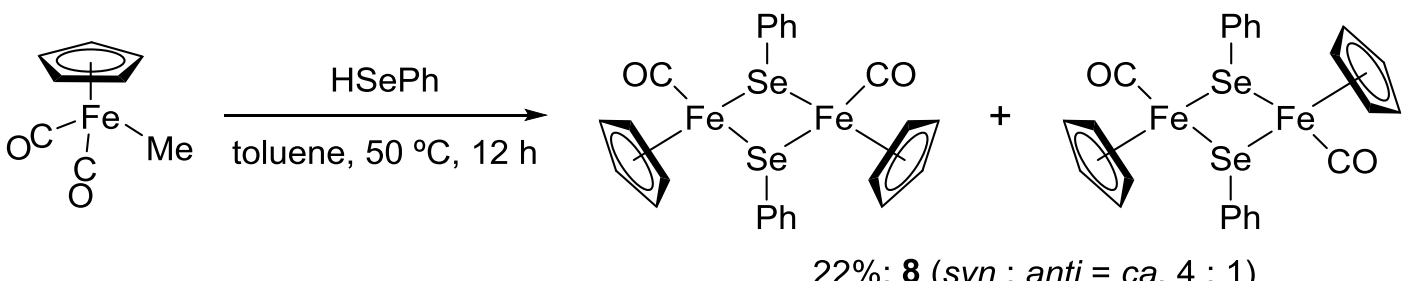

\section{SCHEME 8}

We checked the catalytic activity of $\mathbf{8}$ for dehydrogenative $\mathrm{Sn}-\mathrm{Se}$ bond formation. The reaction of ${ }^{n} \mathrm{Bu}_{3} \mathrm{SnH}$ with $\mathrm{HSePh}$ in the presence of $5 \mathrm{~mol} \%$ of 8 at $50{ }^{\circ} \mathrm{C}$ for $5 \mathrm{~h}$ yielded the desired coupling product ${ }^{n} \mathrm{Bu}_{3} \mathrm{Sn}-\mathrm{SePh}$ in $87 \%$ yield (Scheme 9). 


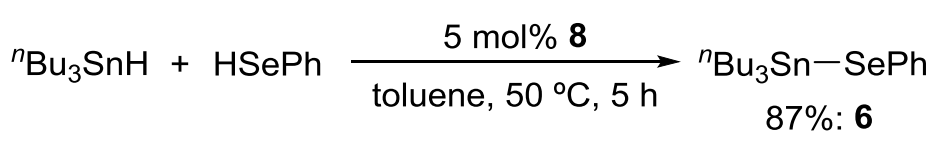

\section{SCHEME 9}

In addition, the hydrido signal $(\delta-13.17)$ of $\mathrm{CpFe}(\mathrm{CO})(\mathrm{H})\left(\mathrm{Sn}^{n} \mathrm{Bu}_{3}\right)_{2}[6]$ was observed by the reaction of $\left[\mathrm{CpFe}(\mathrm{CO})_{2}(\mathrm{Me})\right]$ with 10 equiv. of ${ }^{n} \mathrm{Bu}_{3} \mathrm{SnH}$ at $50{ }^{\circ} \mathrm{C}$ for $15 \mathrm{~min}$ in $\mathrm{C}_{6} \mathrm{D}_{6}$. Then, 10 equiv. of $\mathrm{HSePh}$ was added. After $5 \mathrm{~h}$ at $50{ }^{\circ} \mathrm{C}$, the corresponding coupling compound ${ }^{n} \mathrm{Bu}_{3} \mathrm{Sn}-\mathrm{SePh}$ was obtained in $94 \%$ yield (Scheme 10 ).

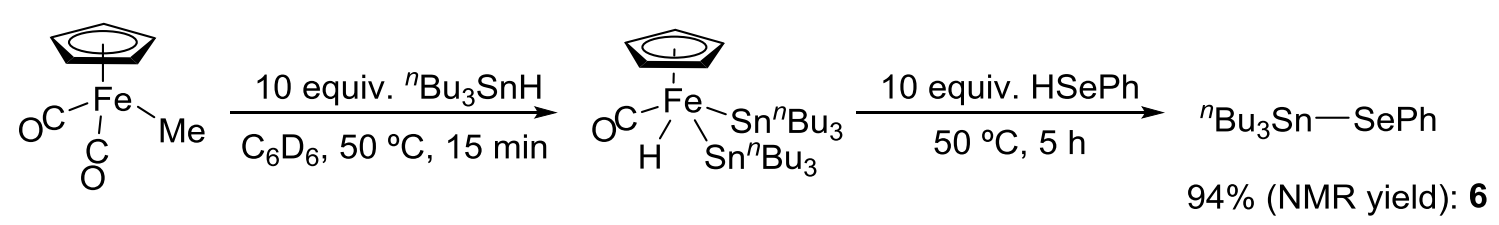

\section{SCHEME 10}

These results show that 8 and $\mathrm{CpFe}(\mathrm{CO})(\mathrm{H})\left(\mathrm{SnR}_{3}\right)_{2}$ are important catalytic intermediates in this system.

A plausible reaction pathway for the dehydrogenative $\mathrm{Sn}-\mathrm{E}(\mathrm{E}=\mathrm{S}, \mathrm{Se})$ bond formation is exhibited in Scheme 11. A methyl migration in the precursor $\left[\mathrm{CpFe}(\mathrm{CO})_{2}(\mathrm{Me})\right]$ forms an acyl complex $\mathrm{CpFe}(\mathrm{CO})\{\mathrm{C}(=\mathrm{O}) \mathrm{Me}\} \quad \mathbf{A}$, which reacts with $\mathrm{R}_{3} \mathrm{SnH}$ (or HER') to give $\mathrm{CpFe}(\mathrm{CO})(\mathrm{H})\{\mathrm{C}(=\mathrm{O}) \mathrm{Me}\}\left(\mathrm{SnR}_{3}\right) \quad$ B $\quad$ (or $\quad \mathrm{CpFe}(\mathrm{CO})(\mathrm{H})\{\mathrm{C}(=\mathrm{O}) \mathrm{Me}\}\left(\mathrm{ER}^{\prime}\right) \quad$ C). Reductive elimination of acetoaldehyde produces $\mathrm{CpFe}(\mathrm{CO})\left(\mathrm{SnR}_{3}\right) \mathbf{D}$ (or $\mathrm{CpFe}(\mathrm{CO})\left(\mathrm{ER}^{\prime}\right) \mathbf{E}$ ). Both the reaction of $\mathbf{D}$ with HER' and that of $\mathbf{E}$ with $\mathrm{R}_{3} \mathrm{SnH}$ produce $\mathrm{CpFe}(\mathrm{CO})(\mathrm{H})\left(\mathrm{SnR}_{3}\right)\left(\mathrm{ER}^{\prime}\right) \mathbf{F}$. The subsequent reductive elimination yields the corresponding coupling product $\mathrm{R}_{3} \mathrm{Sn}-\mathrm{ER}$ ' and hydrido complex $\mathrm{CpFe}(\mathrm{CO})(\mathrm{H})$ G. Oxidative addition of $\mathrm{R}_{3} \mathrm{SnH}$ (or HER') toward the Fe center gives a dihydrido complex $\mathrm{CpFe}(\mathrm{CO})(\mathrm{H})_{2}\left(\mathrm{SnR}_{3}\right) \mathbf{H}$ (or $\mathrm{CpFe}(\mathrm{CO})\left(\mathrm{H}_{2}\left(\mathrm{SnR}_{3}\right)\left(\mathrm{ER}^{\prime}\right) \mathbf{I}\right)$. Reductive elimination of $\mathrm{H}_{2}$ reproduces $\mathbf{D}$ (or $\mathbf{E}$ ) to complete the catalytic cycle. A 16e stannyl complex D 
has a possibility to react with $\mathrm{R}_{3} \mathrm{SnH}$ present in solution to give a bis(stannyl)hydridoiron complex, $\mathrm{CpFe}(\mathrm{CO})(\mathrm{H})\left(\mathrm{SnR}_{3}\right)_{2}$, through $\mathrm{Sn}-\mathrm{H}$ oxidative addition. These types of addition of hydrosilane and hydrostannane to form bis(silyl)hydridoiron and bis(stannyl)hydridoiron complexes have been reported.[7,8] Unsaturated $\mathbf{E}$ having an ER ligand tends to dimerize to produce saturated $\mathbf{K}$, and they are in equilibrium. This type of equiribrium and the related catalytic cycle for $\mathrm{Si}-\mathrm{S}$ bond formation have been reported.[4] Therefore, the catalytic pathway to form an $\mathrm{Sn}-\mathrm{S}$ and $\mathrm{Sn}-\mathrm{Se}$ bond shown in Scheme 11 seems to be reasonable.

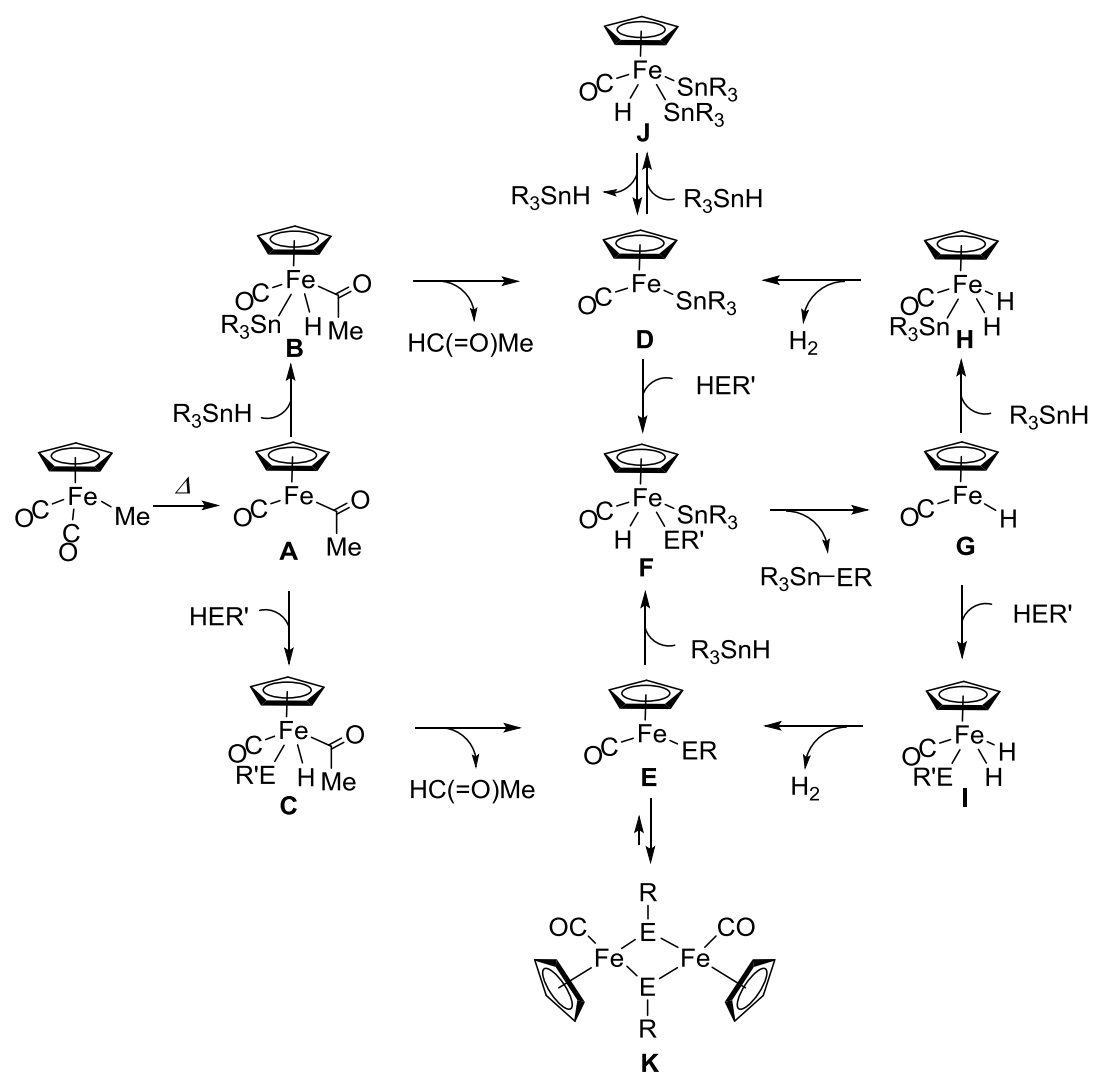

\section{SCHEME 11}

\section{CONCLUSION}

We found that the first examples of iron-catalyzed formation of $\mathrm{Sn}-\mathrm{S}$ and $\mathrm{Sn}-\mathrm{Se}$ bond in the dehydrogenation of thiol and selenol with hydrostannane, respectively. We proposed a 
catalytic cycle, and it was revealed that $[\mathrm{CpFe}(\mathrm{CO})(\mu-\mathrm{SePh})]_{2} 8$ and $\mathrm{CpFe}(\mathrm{CO})(\mathrm{H})\left(\mathrm{SnR}_{3}\right)_{2}$ were important catalytic intermediates in this system.

\section{EXPERIMENTAL}

\subsection{Instrumentation and Chemicals}

All manipulations were carried out using standard Schlenk techniques under a dry nitrogen atmosphere. Iron complex $\mathrm{CpFe}(\mathrm{CO})_{2}(\mathrm{Me})$ [9] was prepared according to the literature method. The other chemicals were commercially available. Spectroscopic data of the products obtained in this work, $\mathbf{1}$ [10], 2 [11], 6 [12], 7 [13], 8 [14] agreed with those in the literatures. Solvents were purified employing a two-column solid-state purification system or were distilled from appropriate drying agents under $\mathrm{N}_{2}$. NMR spectra $\left({ }^{1} \mathrm{H},{ }^{13} \mathrm{C}\left\{{ }^{1} \mathrm{H}\right\},{ }^{77} \mathrm{Se}\left\{{ }^{1} \mathrm{H}\right\}\right.$ and $\left.{ }^{119} \mathrm{Sn}\left\{{ }^{1} \mathrm{H}\right\}\right)$

were recorded on a JNM AL-400 spectrometer. ${ }^{1} \mathrm{H}$ and ${ }^{13} \mathrm{C}\left\{{ }^{1} \mathrm{H}\right\}$ NMR data were referred to residual peaks of solvent as an internal standard, and ${ }^{77} \mathrm{Se}\left\{{ }^{1} \mathrm{H}\right\}$ and ${ }^{119} \mathrm{Sn}\left\{{ }^{1} \mathrm{H}\right\}$ NMR chemical shifts were referenced to external $\mathrm{SeMe}_{2}(0 \mathrm{ppm})$ and $\mathrm{SnMe}_{4}(0 \mathrm{ppm})$ samples. Elemental analysis data were obtained on a Perkin-Elmer 2400 CHN elemental analyzer.

\subsection{Preparation and NMR experiment}

Preparation of ${ }^{n} \mathrm{Bu}_{2} \mathrm{Sn}(\mathrm{SPh})_{2}(\mathbf{1})$ and ${ }^{n} B u_{2} \mathrm{Sn}\left(S S^{t} B u\right)_{2}(2)$

A toluene- $d_{8}$ solution $(400 \mu \mathrm{L})$ containing ${ }^{n} \mathrm{Bu}_{2} \mathrm{SnH}_{2}(21 \mu \mathrm{L}, 0.10 \mathrm{mmol})$ and thiol $(0.20 \mathrm{mmol}$, $\mathrm{HSPh}$ and $\left.\mathrm{HS}^{t} \mathrm{Bu}\right)$ in the presence of $\mathrm{CpFe}(\mathrm{CO})_{2}(\mathrm{Me})(1.9 \mathrm{mg}, 0.01 \mathrm{mmol})$ was heated at $50{ }^{\circ} \mathrm{C}$ for $5 \mathrm{~h}$ for $\mathrm{HSPh}$ and at $80{ }^{\circ} \mathrm{C}$ for $14 \mathrm{~h}$ for $\mathrm{HS}^{t} \mathrm{Bu}$. Compounds $\mathbf{1}$ and $\mathbf{2}$ formed were identified by comparing their ${ }^{1} \mathrm{H}$ NMR data with those previously reported.[10,11] The yields of $\mathbf{1}$ and $\mathbf{2}$ were determined by ${ }^{1} \mathrm{H}$ NMR measurement using 1,4-dioxane as an internal standard (8.5 $\mu \mathrm{L}, 0.10$ mmol). 
Preparation of 1,1'-(1,3-dithia-2,2-dibutylstanyl)-[3]ferrocenophane (3). A toluene solution $(250 \mu \mathrm{L})$ containing $\mathrm{CpFe}(\mathrm{CO})_{2}(\mathrm{Me})(5.8 \mathrm{mg}, 0.03 \mathrm{mmol}),\left[(\mathrm{HSCp})_{2} \mathrm{Fe}\right](75.0 \mathrm{mg}, 0.30 \mathrm{mmol})$, and ${ }^{n} \mathrm{Bu}_{2} \mathrm{SnH}_{2}(65 \mu \mathrm{L}, 0.30 \mathrm{mmol})$ was stirred at $80{ }^{\circ} \mathrm{C}$. After $5 \mathrm{~h}$, volatile materials in the resulting solution were removed under reduced pressure. The residue was purified directly by flash chromatography (alumina, hexane). Evaporation of volatile materials from the eluate led to the formation of $\mathbf{3}$ as a yellow powder (128 mg, 88\%). Single-crystals of $\mathbf{3}$ were obtained by slow evaporation of ether containing 3. NMR spectroscopic analysis: ${ }^{1} \mathrm{H}$ NMR (400 MHz, $\mathrm{C}_{6} \mathrm{D}_{6}$, $\delta$, ppm): 0.83 (t, $\left.J(\mathrm{H}-\mathrm{H})=7.4 \mathrm{~Hz}, 6 \mathrm{H}, \mathrm{CH}_{3}\right), 1.24-1.44\left(\mathrm{~m}, 8 \mathrm{H}, \mathrm{CH}_{3} \mathrm{CH}_{2} \mathrm{CH}_{2} \mathrm{CH}_{2} \mathrm{Sn}\right.$ ), 1.64 (quintet, $J(\mathrm{H}-\mathrm{H})=7.4 \mathrm{~Hz}, 4 \mathrm{H}, \mathrm{CH}_{3} \mathrm{CH}_{2} \mathrm{CH}_{2} \mathrm{CH}_{2} \mathrm{Sn}$ ), 3.84 (br, 4H, Cp), 4.05 (br, 4H, Cp); ${ }^{13} \mathrm{C}\left\{{ }^{1} \mathrm{H}\right\}$ NMR (100.4 MHz, $\left.\mathrm{C}_{6} \mathrm{D}_{6}, \delta, \mathrm{ppm}\right): 13.76$ (s, Bu), 21.03 (s, Bu), 26.98 (s, Bu), 28.71 (s, Bu), 68.72 (s, Cp), 74.61 (s, Cp), 86.23 (s, Cp-ipso). Elemental Analysis: Calcd. For $\mathrm{C}_{18} \mathrm{H}_{26} \mathrm{SnS}_{2} \mathrm{Fe}: \mathrm{C}, 44.94 ; \mathrm{H}, 5.45 \%$; Found: C, 44.98; H, 5.55\%.

Preparation of 1,1'-(1,3-diselena-2,2-dibutylstanyl)-[3]ferrocenophane (4). A toluene solution $(250 \mu \mathrm{L})$ containing $\mathrm{CpFe}(\mathrm{CO})_{2}(\mathrm{Me})(5.8 \mathrm{mg}, 0.03 \mathrm{mmol})$, [(HSeCp$\left.)_{2} \mathrm{Fe}\right](104.0 \mathrm{mg}, 0.30 \mathrm{mmol})$, and ${ }^{n} \mathrm{Bu}_{2} \mathrm{SnH}_{2}(65 \mu \mathrm{L}, 0.30 \mathrm{mmol})$ was stirred at $50{ }^{\circ} \mathrm{C}$. After $4 \mathrm{~h}$, volatile materials in the resulting solution were removed under reduced pressure. To this reaction mixture was added hexane $(2 \mathrm{~mL}), \mathrm{MgSO}_{4}$, and $\mathrm{Na}_{2} \mathrm{SO}_{4}$ and then the entire mixture was stirred for $1 \mathrm{~h}$. The mixture was filtered to remove insoluble materials and then teh filtrate was evaporated to remove volatile materials, resulting in the formation of 4 as an orange-yellow powder (149 mg, 86\%). NMR spectroscopic analysis: ${ }^{1} \mathrm{H}$ NMR (400 MHz, $\left.\mathrm{C}_{6} \mathrm{D}_{6}, \delta, \mathrm{ppm}\right): 0.84\left(\mathrm{t}, J(\mathrm{H}-\mathrm{H})=7.2 \mathrm{~Hz}, 6 \mathrm{H}, \mathrm{CH}_{3}\right)$, $1.31\left(\right.$ sext, $\left.J(\mathrm{H}-\mathrm{H})=7.2 \mathrm{~Hz}, 4 \mathrm{H}, \mathrm{CH}_{3} \mathrm{CH}_{2} \mathrm{CH}_{2} \mathrm{CH}_{2}\right), 1.39\left(\mathrm{t}, J(\mathrm{H}-\mathrm{H})=7.2 \mathrm{~Hz}, 4 \mathrm{H}, \mathrm{SnCH}_{2}\right), 1.64$ (quin, $\left.J(\mathrm{H}-\mathrm{H})=7.2 \mathrm{~Hz}, 4 \mathrm{H}, \mathrm{CH}_{3} \mathrm{CH}_{2} \mathrm{CH}_{2} \mathrm{CH}_{2}\right), 3.85(\mathrm{t}, J(\mathrm{H}-\mathrm{H})=2.0 \mathrm{~Hz}, 4 \mathrm{H}, \mathrm{Cp}), 4.05(\mathrm{t}, J(\mathrm{H}-$ $\mathrm{H})=2.0 \mathrm{~Hz}, 4 \mathrm{H}, \mathrm{Cp}) ;{ }^{13} \mathrm{C}\left\{{ }^{1} \mathrm{H}\right\} \mathrm{NMR}\left(100.4 \mathrm{MHz}, \mathrm{C}_{6} \mathrm{D}_{6}, \delta, \mathrm{ppm}\right): 113.81\left(\mathrm{~s}, \mathrm{SnCH}_{2}\right), 20.62(\mathrm{~s}$, $\mathrm{CH}_{3}$ ), 26.95 (s, $\mathrm{CH}_{3} \mathrm{CH}_{2} \mathrm{CH}_{2} \mathrm{CH}_{2}$ ), 29.39 (s, $\mathrm{CH}_{3} \mathrm{CH}_{2} \mathrm{CH}_{2} \mathrm{CH}_{2}$ ), 69.09 (s, Cp), 75.88 (s, Cp), 79.26 (s, Cp-ipso); ${ }^{77} \mathrm{Se}\left\{{ }^{1} \mathrm{H}\right\}$ NMR $\left(76.1 \mathrm{MHz}, \mathrm{C}_{6} \mathrm{D}_{6}, \mathrm{ppm}\right): \delta-210.10\left(\mathrm{~s}, J\left({ }^{117} \mathrm{Sn}-{ }^{-77} \mathrm{Se}\right)=1270\right.$ $\left.\mathrm{Hz}, J\left({ }^{119} \mathrm{Sn}-{ }^{77} \mathrm{Se}\right)=1331 \mathrm{~Hz}, \mathrm{SnSeC}_{5} \mathrm{H}_{4}\right) ;{ }^{119} \mathrm{Sn}\left\{{ }^{1} \mathrm{H}\right\} \mathrm{NMR}\left(148.9 \mathrm{MHz}, \mathrm{C}_{6} \mathrm{D}_{6}, \mathrm{ppm}\right): \delta 161.56(\mathrm{~s}$, 
$\left.J\left({ }^{77} \mathrm{Se}-{ }^{119} \mathrm{Sn}\right)=1331 \mathrm{~Hz}\right)$. Elemental Analysis: Calcd. For $\mathrm{C}_{18} \mathrm{H}_{26} \mathrm{Se}_{2} \mathrm{SnFe}$ : C, 37.61; H, 4.56\%;

Found: C, 37.66; H, $4.80 \%$.

Preparation of 1,1'-bis(tributylstanylseleno)ferrocene (5). A toluene solution $(250 \mu \mathrm{L})$ containing $\mathrm{CpFe}(\mathrm{CO})_{2}(\mathrm{Me})(5.8 \mathrm{mg}, 0.03 \mathrm{mmol}),\left[(\mathrm{HSCp})_{2} \mathrm{Fe}\right](75.0 \mathrm{mg}, 0.30 \mathrm{mmol})$, and ${ }^{n} \mathrm{Bu} \mathrm{u}_{3} \mathrm{SnH}(156 \mu \mathrm{L}, 0.60 \mathrm{mmol})$ was stirred at $50{ }^{\circ} \mathrm{C}$. After $6 \mathrm{~h}$, volatile materials in the resulting solution were removed under reduced pressure. To this reaction mixture was added hexane (2 $\mathrm{mL}$ ), $\mathrm{MgSO}_{4}$, and $\mathrm{Na}_{2} \mathrm{SO}_{4}$ and then the entire mixture was stirred for $1 \mathrm{~h}$. The mixture was filtered to remove insoluble materials and then the filtrate was evaporated to remove volatile materials, resulting in the formation of $\mathbf{5}$ as a yellow oil (274 mg, 93\%). NMR spectroscopic analysis: ${ }^{1} \mathrm{H}$ NMR $\left(400 \mathrm{MHz}, \mathrm{C}_{6} \mathrm{D}_{6}, \delta, \mathrm{ppm}\right): 0.89\left(\mathrm{t}, J(\mathrm{H}-\mathrm{H})=7.3 \mathrm{~Hz}, 18 \mathrm{H}, \mathrm{CH}_{3}\right), 1.07(\mathrm{t}, J(\mathrm{H}-$ $\left.\mathrm{H})=7.3 \mathrm{~Hz}, 12 \mathrm{H}, \mathrm{CH}_{3} \mathrm{CH}_{2} \mathrm{CH}_{2} \mathrm{CH}_{2}\right), 1.30\left(\mathrm{sext}, J(\mathrm{H}-\mathrm{H})=7.3 \mathrm{~Hz}, 12 \mathrm{H}, \mathrm{CH}_{3} \mathrm{CH}_{2} \mathrm{CH}_{2} \mathrm{CH}_{2}\right), 1.56$ (quin, $\left.J(\mathrm{H}-\mathrm{H})=8.3 \mathrm{~Hz}, 12 \mathrm{H}, \mathrm{CH}_{3} \mathrm{CH}_{2} \mathrm{CH}_{2} \mathrm{CH}_{2}\right), 4.11(\mathrm{~s}, 4 \mathrm{H}, \mathrm{Cp}), 4.42(\mathrm{~s}, 4 \mathrm{H}, \mathrm{Cp}) ;{ }^{13} \mathrm{C}\left\{{ }^{1} \mathrm{H}\right\}$ NMR (100.4 MHz, $\mathrm{C}_{6} \mathrm{D}_{6}, \delta, \mathrm{ppm}$ ): 13.92 (s, $\mathrm{SnCH}_{2}$ ), 14.04 (s, $\mathrm{CH}_{3}$ ), 27.45 (s, $\mathrm{CH}_{3} \mathrm{CH}_{2} \mathrm{CH}_{2} \mathrm{CH}_{2}$ ), 29.36 (s, $\mathrm{CH}_{3} \mathrm{CH}_{2} \mathrm{CH}_{2} \mathrm{CH}_{2}$ ), 70.02 (s, Cp), 71.43 (s, $\mathrm{Cp}$ ), 77.88(s, Cp-ipso). Elemental Analysis: Calcd. For $\mathrm{C}_{34} \mathrm{H}_{64} \mathrm{Se}_{2} \mathrm{Sn}_{2} \mathrm{Fe}$ : C, 44.29; H, 6.78\%; Found: C, 44.70; H, 7.00\%.

Preparation of ${ }^{n} \mathrm{Bu}_{3} \mathrm{SnSePh}(\mathbf{6})$ and $\mathrm{Ph}_{3} \mathrm{SnSePh}$ (7)

Benzeneselenol $(11 \mu \mathrm{L}, 0.10 \mathrm{mmol})$ was treated with ${ }^{n} \mathrm{Bu}_{3} \mathrm{SnH}$ for 6 and $\mathrm{Ph}_{3} \mathrm{SnH}$ for $7(0.10$ $\mathrm{mmol})$ in the presence of $\mathrm{CpFe}(\mathrm{CO})_{2}(\mathrm{Me})(1.9 \mathrm{mg}, 0.01 \mathrm{mmol})$ in toluene- $d_{8}(400 \mu \mathrm{L})$. at $50{ }^{\circ} \mathrm{C}$ for 5. Compounds 6 and 7 were identified by comparing their ${ }^{1} \mathrm{H}$ NMR data with those previously reported.[11,12] The yields of 6 and 7 were determined by ${ }^{1} \mathrm{H}$ NMR measurement using 1,4-dioxane as an internalstandard $(8.5 \mu \mathrm{L}, 0.10 \mathrm{mmol})$.

Preparation of $[\mathrm{CpFe}(\mathrm{CO})(\mu-\mathrm{SePh})]_{2} 8$

An acetonitrile solution $(5 \mathrm{~mL})$ containing $\mathrm{CpFe}(\mathrm{CO})_{2}(\mathrm{Me})(192 \mathrm{mg}, 1.0 \mathrm{mmol})$ and benzeneselenol $(106 \mu \mathrm{L}, 1.0 \mathrm{mmol})$ was stirred at $50^{\circ} \mathrm{C}$. After $12 \mathrm{~h}$, volatile materials in the 
resulting solution were removed under reduced pressure. To this reaction mixture was purified by reprecipitation from dichloromethane $(1 \mathrm{~mL})$ by hexane $(10 \mathrm{~mL})$. The obtained precipitate was filtered and dried to give 8 (syn : anti $=c a .4: 1)$ as a brown powder (66 mg, 22\%). Complex 8 was identified by comparing their ${ }^{1} \mathrm{H}$ NMR data with those previously reported.[14]

\section{NMR experiment}

A $\mathrm{C}_{6} \mathrm{D}_{6}$ solution $(500 \mu \mathrm{L})$ containing $\mathrm{CpFe}(\mathrm{CO})_{2}(\mathrm{Me})(3.8 \mathrm{mg}, 0.02 \mathrm{mmol}),{ }^{n} \mathrm{Bu}_{3} \mathrm{SnH}(53.8 \mu \mathrm{L}$, $0.2 \mathrm{mmol})$ and 1,4-dioxane $(17.1 \mu \mathrm{L}, 0.2 \mathrm{mmol})$ as an internal standard was placed in an NMR tube with a Teflon cap. The sample was heated at $50{ }^{\circ} \mathrm{C}$. After $15 \mathrm{~min}$, the hydrido signal $(\delta-$ 13.17) of $\mathrm{CpFe}(\mathrm{CO})(\mathrm{H})\left(\mathrm{Sn}^{n} \mathrm{Bu}_{3}\right)_{2}$ was observed by the ${ }^{1} \mathrm{H}$ NMR spectrum and then benzeneselenol $(21.2 \mu \mathrm{L}, 0.2 \mathrm{mmol})$ was added in the reaction mixture. The sample was heated at $50{ }^{\circ} \mathrm{C}$ for $5 \mathrm{~h}$. The yield (94\%) of formed ${ }^{n} \mathrm{Bu}_{3} \mathrm{Sn}-\mathrm{SePh}$ was determined by ${ }^{1} \mathrm{H}$ NMR.

\subsection{Crystal structure determination and refinement}

X-ray intensity data were collected on a Rigaku/MSC Mercury CCD diffractometer with graphite monochromated Mo-K $\alpha$ radiation. Calculations were performed with the CrystalClear software package of Molecular Structure Corporation. The structure was solved by direct methods and expanded using Fourier techniques. The structure was refined by full matrix leastsquares technique using the program SHELXL-2014.[15] The non-hydrogen atoms were refined anisotropically. All hydrogen atoms were placed in calculated positions. Complex $\mathbf{3}$ has been deposited with the Cambridge Crystallographic Data Centre under CCDC 1871153. These data can be obtained free of charge via www.ccdc.cam.ac.uk/conts/retrieving.html (or from the Cambridge Crystallographic Data Centre, 12 Union Road, Cambridge CB2 1EZ, UK; Tel.; +44 1223 336408; Fax: +44 1223 336033; E-mail: deposit@ccdc.cam.ac.uk). 


\section{ACKNOWLEDGEMENTS}

This work was supported by a Grant-in-Aid for Scientific Research from JSPS (Category C, No. 16K05728 (M.I.)), and by a Grant-in Aid for Scientific Research on Innovation Area "Stimuliresponsive Chemical Species for the Creation of Functional Molecules" (No. 15H00957 (H.N.)) from JSPS, Japan. 


\section{REFERENCES}

[1] D. N. Harpp.; T. Aide; T. H. Chan, Tetrahedron Lett., 1979, 2853-2856.

[2] Y. Nisiyama, H. Ohashi, K. Itoh, N. Sonoda, Chem. Lett., 1998, 27, 159-160.

[3] J. J. Talley, A. M. Colley, J. Organomet. Chem., 1981, 215, C38-C40.

[4] K. Fukumoto, M. Kasa, T. Oya, M. Itazaki, H. Nakazawa, Organometallics, 2011, 30, 3461-3463.

[5] S. Zürcher, V. Gramlich, A. Togni, Inorg. Chim. Acta, 1999, 291, 355-364.

[6] S. Zhang, T. L. Brown, Organometallics, 1992, 11, 2122-2128.

[7] (a) M. Akita, T. Oku, M. Tanaka and Y. Moro-oka, Organometallics, 1991, 10, 30803089; (b) M. Akita, T. Oku and Y. Moro-oka, J. Chem. Soc., Chem. Commun., 1989, 1790-1792.

[8] (a) M. Itazaki, K. Ueda, and H. Nakazawa, Angew. Chem., Int. Ed., 2009, 48, 3313. ibid 2009, 48, 6938. (b) M. Itazaki, M. Kamitani, K. Ueda, and H. Nakazawa, Organometallics, 2009, 28, 3601.

[9] T. S. Piper, G. Wilkinson, J. Inorg. Nucl. Chem. 1956, 3, 104-124.

[10] L. Antonin, H. Jqraoslav, H. Karel, Collect. Czech. Chem. Commun., 1989, 54, 23862398.

[11] D. Sukhani, V. D. Gupta, R. C. Mehrotra, J. Organomet. Chem., 1967, 7, 85-90.

[12] D. W. Grant, J. L. Wardell, J. Organomet. Chem., 1984, 276, 161-166.

[13] Y. Nishiyama, H. Kawamatsu, S. Funato, K. Tokunaga, N. Sonoda, J. Org. Chem., 2003, $68,3599-3602$.

[14] K. Geetharani, S. K. Bose, D. Basak, V. M. Suresh, S. Ghosh, Inorg. Chim. Acta, 2011, $372,42-46$.

[15] Sheldrick, G. M. SHELXL-2014: Program for the Refinement of Crystal Structures. University of Göttingen, Germany (2014). 